\title{
A comparison of the absorbed fluorescent treponemal antibody (FTA-ABS) test and other screening tests for treponemal disease in patients attending a venereal disease clinic
}

\author{
A. E. WILKINSON, G. SCRIMGEOUR, AND P. RODIN \\ From the Venereal Disease Reference Laboratory, The London Hospital
}

SYNOPSIS Screening tests-absorbed fluorescent treponemal (FTA-ABS), the Reiter protein complement-fixation (RPCFT), VDRL slide test, automated reagin - and cardiolipin Wassermann reaction-were carried out on 1922 consecutive new patients attending the WhitechapelClinicover a three-month period.

Taking the FTA-ABS test results as an index, the most efficient combination of conventional tests was found to be the RPCFT and automated reagin test. The cardiolipin WR proved to be undersensitive and of little value compared with the other tests.

Forty-two per cent of the 107 sera reactive in the FTA-ABS test were not detected by the RPCFT or ART tests. An assessment based on the TPI test results and clinical findings in these patients is presented.

The scope and limitations of the FTA-ABS test as a screening procedure are discussed.

Tests for treponemal infection are an integral part of the routine investigation of all patients attending venereal disease clinics. In the past, reliance has been mainly placed on tests in which lipoidal antigens are used because these are technically easy to perform on large numbers of sera and have a high sensitivity. The Reiter protein complement-fixation test (RPCFT), which detects group specific antitreponemal antibody and is more specific than the lipoidal tests, is often used in combination with the latter to provide a more effective screen. Use of the most specific test available, the Treponema pallidum immobilization (TPI) test, is not practicable because of its complexity and expense, but the introduction of the absorbed fluorescent treponemal antibody (FTA-ABS) test by Hunter, Deacon, and Meyer (1964) has provided a test of high specificity and sensitivity by which relatively large numbers of sera can be examined. Cohen, Stout, and Ende (1969) reported on the use of this test in examining 463 unselected patients admitted to a general hospital and found it reactive in $16.8 \%$ compared with $9.5 \%$ by the VDRL slide test which has been very widely used as a screening test. O'Neill, Johnson, and Nicol (1970) compared the results of the FTA-ABS test with those of the RPCFT, Price's precipitation reaction, and a Received for publication 20 October 1971. cardiolipin Wassermann reaction on 1897 sera from unselected patients attending a venereal diseases clinic. Reactivity in the tests was: FTA-ABS, 509; RPCFT, 315; PPR or CWR, 161. The use of the FTA-ABS test resulted in the detection of a considerable number of patients with treponemal infections which would not have been found by the other screening tests used.

\section{The Present Investigation}

Sera were tested from 1922 consecutive patients attending the Whitechapel Clinic over a period of three months. These included a number of old patients who re-attended with disease other than that for which they had originally been treated. The following tests were performed: (1) the FTA-ABS test by the technique described by the Venereal Disease Research Laboratory (Atlanta) (1968), but using sorbent and antigen prepared in the laboratory. Sera giving doubtful $(+)$ results or results not confirmed by positive results with the other screening tests were repeated using an ultrasonicate of Reiter treponemes in place of sorbent and testing the absorbed serum against both $T$. pallidum and Reiter treponemes as antigens. Results were not accepted as valid unless the former showed at least + 
fluorescence while no fluorescence was seen with Reiter treponemes, indicating effective removal of group antitreponemal antibody (Wilkinson and Wiseman, 1971); (2) the Reiter protein complementfixation test; (3) the cardiolipin Wassermann reaction; (4) the VDRL slide test; and (5) the automated reagin (ART) test (McGrew, DuCros, Stout, and Falcone (1968), using RPR antigen prepared in the laboratory.

TPI tests were performed on sera which gave isolated positive or doubtful $(+)$ results in the FTAABS test or when the screening tests gave discrepant results.

The aims of the study were twofold: $(a)$ to determine the most sensitive screening tests, singly or in combination, in terms of the patients judged to have treponemal infection on the basis of reactive FTA-ABS tests and clinical assessment ; $(b)$ To assess the significance of reactive FTA-ABS tests in the absence of confirmation from other positivescreening tests.

\section{Results}

RACIAL COMPOSITION OF THE PATIENTSSTUDIED This is analysed in Table I.

The majority of the patients were natives of the United Kingdom or Eire or came from the Caribbean area (317) or West Africa (27). These last are areas where yaws is, or has been, endemic so that patients coming from these regions are considered together.

The FTA-ABS test was found positive on 79 sera and gave a doubtful $(+)$ result with a further 28 , giving a total reactivity of $107(5.6 \%)$ among the whole population tested. The incidence of reactivity in the different racial groups is shown in Table II.
These figures show clearly that by far the highest incidence of reactivity in the FTA-ABS test was found among patients coming from the Caribbean or West Africa. The incidence was also high among the group of Indians and Pakistanis but as this group is relatively small, the result may be misleading.

SENSITIVITY OF THE SCREENING TESTS IN TERMS OF REACTIVE FTA-ABS TESTS

Of the 107 sera which gave positive or doubtful $\vec{\circ}$ FTA-ABS tests, the reactivity in the other four $\vec{\overrightarrow{ }}$ screening tests was: RPCFT 55 (51.5\%); ART 44 $(41 \cdot 1 \%)$; VDRL $36(33.6 \%)$; and CWR $19(17 \cdot 7 \%)$.

All four of the other screening tests were negative on 45 of the sera $(42 \%)$ and in a further $17(15.9 \%) \mathrm{cr}$ the RPCFT was the only one positive. A combination $\mathrm{G}$ of the RPCFT and the ART gave the highest yield, 62 sera $(57.9 \%)$ being reactive in one or both of these 0 two tests. The RPCFT and/or the VDRL test were positive on 55 sera $(51 \cdot 4 \%)$. The cardiolipin WR $\vec{z}$ proved to be considerably less sensitive than the two flocculation tests and in this series it was never found $\rightarrow$ positive unless either the RPCFT or one or both the flocculation tests gave positive results. From this : series it seemed that a combination of the RPCFT and the ART would provide the highest yield from patients with potential treponemal disease.

CLINICAL ASSESSMENT OF THE RESULTS Either the RPCFT or the ART or both tests were $\overrightarrow{\bar{a}}$ found positive or weakly positive on 62 of the $107 \frac{\mathrm{O}}{3}$ sera on which the FTA-ABS test had been found $\supsetneq$ reactive. An assessment in terms of the TPI test result, when this had been done, and the clinical findings, is given in Table IIIa. A similar assessment of the results on 45 sera, $42 \%$ of the total, on which

\begin{tabular}{|c|c|c|c|}
\hline Country of Origin & Males & Females & Total \\
\hline $\begin{array}{l}\text { United Kingdom and Eire } \\
\text { Other European } \\
\text { Turkey, Cyprus, Malta } \\
\text { Caribbean, West Africa } \\
\text { India, Pakistan } \\
\text { Other }\end{array}$ & $\begin{array}{rr}831 & (66.7 \%) \\
32 & (2.6 \%) \\
47 & (3.8 \%) \\
231 & (18.6 \%) \\
55 & (4.5 \%) \\
48 & (3.9 \%) \\
1244 & \end{array}$ & $\begin{array}{rr}515 & (76.0 \%) \\
23 & (3.3 \%) \\
5 & (0.7 \%) \\
113(16.7 \%) \\
4(0.6 \%) \\
18(2.6 \%) \\
678\end{array}$ & $\begin{array}{r}1346(70.03 \%) \\
55(2.86 \%) \\
52(2.71 \%) \\
344(17.90 \%) \\
59(3.07 \%) \\
66(3.43 \%) \\
1922\end{array}$ \\
\hline
\end{tabular}

Table I Country of origin of patients surveyed

\begin{tabular}{|c|c|c|c|c|}
\hline Country of Origin & Patients & $\begin{array}{l}\text { FTA-ABS } \\
\text { Positive }\end{array}$ & $\begin{array}{l}\text { FTA-ABS } \\
\text { Doubtful }\end{array}$ & $\begin{array}{l}\text { Total } \\
\text { Reactive }\end{array}$ \\
\hline $\begin{array}{l}\text { United Kingdom, Eire } \\
\text { Other European } \\
\text { Turkey, Cyprus, Malta } \\
\text { Caribbean, West Africa } \\
\text { India, Pakistan } \\
\text { Other }\end{array}$ & $\begin{array}{r}1346 \\
55 \\
52 \\
344 \\
59 \\
66\end{array}$ & $\begin{aligned} 18 & (1.3 \%) \\
1 & (1.8 \%) \\
0 & \\
54 & (15.7 \%) \\
4 & (6.8 \%) \\
2 & (3.0 \%)\end{aligned}$ & $\begin{array}{r}8(0.6 \%) \\
1(1.8 \%) \\
1(1.9 \%) \\
15(4.4 \%) \\
1(1.7 \%) \\
2(3.0 \%)\end{array}$ & $\begin{array}{rr}26 & (1.9 \%) \\
2 & (3.6 \%) \\
1 & (1.9 \%) \\
69 & (20.1 \%) \\
5 & (8.3 \%) \\
4 & (6.0 \%)\end{array}$ \\
\hline
\end{tabular}

Table II Incidence of reactivity in the FTA-ABS test in the different racial groups 


\begin{tabular}{|c|c|c|c|}
\hline$T P I$ & Assessment & FTA-ABS Positive & FTA-ABS Doubtful \\
\hline Reactive (30) & $\begin{array}{l}\text { Syphilis } \\
\text { History of yaws }\end{array}$ & $\begin{array}{l}7 \text { (UK, 5; Pole, } 1 \text {; Pak, 1) } \\
8 \text { (C) }\end{array}$ & 1 (UK) \\
\hline $\begin{array}{l}\text { Negative (2) } \\
\text { Not done }(30)\end{array}$ & $\begin{array}{l}\text { No evidence } \\
\text { No evidence } \\
\text { Syphilis } \\
\text { History of yaws } \\
\text { No evidence }\end{array}$ & $\begin{array}{l}11 \text { (C, 10; EA, 1) } \\
1 \text { (Egyptian) } \\
9 \text { (UK, 5; C, 2; Ind, 2) } \\
8 \text { (C, 7; WA, 1) } \\
12 \text { (C) }\end{array}$ & $\begin{array}{l}3 \text { (C, 2: UK, 1) } \\
1 \text { (French) } \\
1 \text { (C) }\end{array}$ \\
\hline
\end{tabular}

Table IIIa Assessment of results on 62 sera with reactive FTA-ABS tests and reactive RPCFT and/or AR tests

\begin{tabular}{|c|c|c|c|}
\hline$T P I$ & Assessment & FTA-ABS Positive & FTA-ABS Doubtful \\
\hline $\begin{array}{l}\text { Reactive (29) } \\
\text { Negative (13) } \\
\text { Not done (3) (2 NVT) }\end{array}$ & $\begin{array}{l}\text { Syphilis } \\
\text { History of yaws } \\
\text { No evidence } \\
\text { Syphilis } \\
\text { No evidence } \\
\text { No evidence }\end{array}$ & $\begin{array}{l}1 \text { (UK) } \\
2 \text { (C) } \\
13 \text { (C, } 8, \text { UK, } 3 \text {; WA, 1; Pak, 1) } \\
2 \text { (UK) } \\
4 \text { (UK, 2; C, 2) } \\
1 \text { (WA) }\end{array}$ & $\begin{array}{l}13 \text { (C, 9; UK, } 1 \text {; Arab, } 1 \text {; Cypriot, } 1 \text {; WA , 1) } \\
2 \text { (UK, 1; Israeli, 1) } \\
5 \text { (UK, 4; Ind, 1) } \\
2 \text { (C) }\end{array}$ \\
\hline
\end{tabular}

Table IIIb Assessment of results on 45 sera giving reactive FTA-ABS tests but negative RPCFT and AR tests $\mathrm{UK}=$ United Kingdom; C = Caribbean; WA = West African; EA = East African; Pak = Pakistani; Ind = Indian; NVT = no valid test

the FTA-ABS test was reactive but both the RPCF and AR tests were found negative is shown in Table IIIb.

In the 62 sera assessed in Table IIIa in which beside a reactive FTA-ABS test, the RPCFT or AR tests or both were also positive, the presence of treponemal disease was confirmed by a reactive TPI test in 30 and in a further 17 there was either a history of treated or untreated syphilis or of yaws. In the remaining 15 patients, 13 of whom were West Indians, there was no evidence of syphilis and no history of yaws was elicited. In all the 13 West Indians both the RPCFT and the ART were positive, so that on serological grounds the presumption of treponemal disease, past or present, appears to be well founded. In two other patients, one Egyptian and one French, only the RPCFT was positive in addition to the reactive FTA-ABStest; noconclusion was reached about these.

In 45 patients (Table IIIb) only the FTA-ABS test was reactive. TPI tests were done on 42 of these. A reactive TPI test provided evidence of past or present treponemal infection in 29 and a further three British patients and one Israeli patient had a history of syphilis although the TPI was negative. No further evidence of treponemal infection was found in 12 patients. Thus there was good evidence that the FTA-ABS result was specific in $73 \%$ of the 45 patients in this group; these might have passed unnoticed had reliance been placed on the conventional screening tests alone.

FALSE POSITIVE SCREENING TESTS

Sera from nine patients gave reactive screening tests (RPCFT, three; VDRL, three; ART, two; CWR, two) which were thought to be possible false positive reactions because the FTA-ABS test was negative as was the TPI test on seven sera on which it was done. Seven of the patients showed no evidence of treponemal infection but the other two were more debatable. One was a young white woman whose serum showed only a weakly reactive AR test; there was no evidence of infection but her husband had primary syphilis and as she was pregnant, she was given treatment on epidemiological grounds. The second patient was a 29-year-old male West Indian whose serum showed only a weakly reactive VDRL test. He had a history of yaws in early life. In 1962 the TPI test had been positive $(65 \%)$, as were the RPCFT and FTA-200 tests, and treatment with penicillin had then been given. This VDRL result was presumably specific in view of the history.

\section{Discussion}

The most important objective of screening tests from the public health viewpoint is the detection of patients with early syphilis who are potentially able to transmit the disease. In such cases the conventional screening tests are usually unequivocally positive and the addition of the FTA-ABS test would add little to the numbers of cases detected, except perhaps in the earlier detection of some patients with primary syphilis. For the large-scale screening of presumably healthy persons in this country, such as blood donors and pregnant women, in whom the incidence of syphilis is extremely low, the routine use of the FTA-ABS test would be unlikely to yield results commensurate with the labour involved, even though an automated procedure were used. In patients attending venereal disease clinics the incidence of treponemal infection is very much greater and the 
wider use of the FTA-ABS tests in addition to the conventional screening tests on new patients might be expected to increase the number of patients brought to treatment. Under the present conditions in this country many of these would be patients coming from areas where yaws has flourished in the past. Whether the treatment of patients showing only minimal serological residua of a long past infection with yaws is likely to be beneficial is perhaps debatable, but owing to the impossibility of reaching certainty that such reactions are due to yaws and not to syphilis, the policy of offering treatment is generally accepted. If a complete screening of all new patients is not practicable, the use of the FTA-ABS test in those groups of patients in whom treponemal infection is known to be common, such as homosexuals, prostitutes, and certain immigrants, merits consideration.

The finding of a reactive FTA-ABS test, even in isolation, should arouse suspicion of treponemal disease and be fully investigated. Even when the TPI test is found negative, treponemal infection is not absolutely excluded and Atwood, Miller, Stout, and Norins (1968) have reported that some $10 \%$ of patients with old, treated, latent, or late syphilis may show reactive FTA-ABS tests although the TPI test has become negative with the passage of time. False positive FTA tests with sera containing abnormal macroglobulins have been reported by Fife (1964) and an apparent transient false positive FTA-ABS test has been reported in a pregnant woman by Buchanan and Haserick (1970). Atypical reactions may also occur with the serum of some patients with lupus erythematosus (Kraus, Haserick, and Lantz, 1970). Criticisms of the immunological specificity of the sorbent used in the FTA-ABS test have been made by several workers (Cannefax, Hanson, and Skaggs, 1968; Wilkinson and Ferguson, 1968; Rathlev, 1968; Wilkinson and Wiseman, 1971). The use of an ultrasonicate of Reiter treponemes in place of the conventional sorbent is advisable as a confirmatory test when doubtful or unsubstantiated results are obtained with the latter reagent. Unless a serum after absorption can be shown to produce definite fluorescence with $T$. pallidum as antigen but $\stackrel{0}{\overrightarrow{0}}$ not to give fluorescence with Reiter treponemes, thus confirming complete removal of group antibody, the $\overrightarrow{\vec{s}}$ result of the test should not be considered valid. The FTA-ABS test is the most sensitive test for treponemal infection at present available; although it has a high specificity, this is not absolute, and its limita- $\mathbb{\infty}$ tions should be recognized.

We wish to thank the World Health Organization for $\overrightarrow{0}$ financial support and $\mathrm{Mr}$ C. S. Storey, Mr H. R. Ferguson, FIMLT, and Mr S. W. Turner for their ${ }_{\sigma}^{\omega}$ technical assistance.

References

Atwood, W. G., Miller, J. L., Stout, G. W., and Norins, L. C. (1968). i The TPI and FTA-ABS tests in treated late syphilis. J. Amer. med. Ass., 203, 549-551.

Buchanan, C. S., and Haserick, J. R. (1970). FTA-ABS test in preg-O nancy. A probable false positive reaction. Arch. Derm., 102, 322-325.

Cannefax, G. R., Hanson, A. W., and Skaggs, R., Jr, (1968). An investi- $Z$ gation of sorbing substances in the FTA-ABS test for syphilis. ט) Publ. Hlth Rep. (Wash.), 83, 411-416.

Cohen, P., Stout, G., and Ende, N. (1969). Serologic reactivity in $\overrightarrow{0}$ consecutive patients admitted to a general hospital. Arch. Intern. Med., 124, 364-367.

Fife, E. (1964). Influence of macroglobulins on the specificity of fluorescent treponemal antibody (FTA) test for syphilis. In Proceedings of the World Forum on Syphilis and Other Trepon-乏 ematoses (US Public Health Service Publication No. 997), pp. 254-257.

Hunter, E. F., Deacon, W. E., and Meyer, P. E. (1964). An improved ڤ్ FTA test for syphilis. The absorption procedure (FTA-ABS). (D Publ. Hlth Rep. (Wash.), 79, 410-412.

Kraus, S. J., Haserick, J. R., and Lantz, M. A. (1970). Fluorescent $\overrightarrow{\vec{O}}$ treponemal antibody-absorption test reactions in lupus erythematous: atypical beading pattern and probable falsepositive reactions. New Engl.J. Med., 282, 1287-1290.

McGrew, B. E., DuCros, M. J. F., Stout, G. W., and Falcone, V. H.⿱一兀) (1968). Automation of a flocculation test for syphilis. Amer. $J$ clin. Path., 50, 52-59.

O'Neill, P., Johnson, G. D., and Nicol, C. S. (1970). Evaluation of modified FTA-ABS test: multispot FTA-ABS. Brit. J. vener.믐 Dis., 46, 278-283.

Rathlev, T. (1968). Evaluation of the sorbents used in the FTA-ABS test. Brit. J. vener. Dis., 44, 295-298.

Venereal Disease Research Laboratory (Atlanta) (1968) Technic for the fluorescent treponemal antibody-absorption. (FTA-ABS) test 0 Hlth Lab. Sci., 5, 23-30.

Wilkinson, A. E., and Ferguson, H. G. (1968). Some observations on the sorbing agent used in the absorbed fluorescent treponemafo antibody (FTA-ABS) test. Brit. J. vener. Dis., 44, 291-294.

Wilkinson, A. E., and Wiseman, C. C. (1971). The role of sorbent in the absorbed fluorescent treponemal antibody (FTA-ABS) test? Proc. roy. Soc. Med., 64, 422-425. 